\title{
KEEFEKTIFAN STRATEGI PEMBELAJARAN ANTARA METODE TUTOR SEBAYA DENGAN METODE TANYA JAWAB DALAM PENGAJARAN REMIDIAL MATERI FUNGSI LIMIT
}

\author{
UKTI LUTVAIDAH \\ Uktilutvaidah03@gmail.com \\ Program Studi Arsitektur, FTMIPA Universitas Indraprasta PGRI \\ Jl.Nangka 58 Tanjung Barat Jagakarsa Jakarta Selatan
}

\begin{abstract}
Abstrak. Aktivitas belajar tidak selamanya dapat berjalan dengan lancar, peserta didik seringkali mengalami kesulitan dalam belajar, baik dalam hal menerima pelajaran, menyerap pelajaran, atau kedua-duanya. Kesulitan belajar dapat dilihat dengan adanya seorang atau sekelompok peserta didik yang tidak dapat mencapai hasil belajar yang diinginkan.Tujuan penelitian ini adalah untuk mengetahui ada tidaknya perbedaan prestasi belajar matematika antara peserta didik yang diremidi menggunakan metode tutor sebaya dengan peserta didik yang diremidi menggunakan metode tanya jawab. dan jika ada, manakah yang lebih efektif dari dua metode pembelajaran tersebut.Hasil penelitian ini mengambil lokasi di Madrasah Aliyah Negeri Kota Tegal tahun pelajaran 2011/2012. Populasi dalam penelitian ini adalah para peserta didik kelas XI IPS yang nilai ulangan harinya dibawah KKM pada materi fungsi limit semester genap. Sampel sebanyak 2 kelas diambil menggunakan teknik cluster random sampling terambil kelas XI IPS 1 dan XI IPS 2 dengan jumlah 76 peserta didik. Metode pengumpulan data yang dipakai adalah metode dokumentasi dan tes untuk mempereoleh data tentang populasi dan sampel serta prestasi belajar sebelum dan sesudah pengajaran remidial. Analisis data menggunakan uji-t dua pihak digunakan untuk menentukan ada tidaknya perbedaan prestasi belajar matematika antara peserta didik yang diremidi menggunakan kedua metode tersebut dan uji-t satu pihak untuk untuk menetukan metode pembelajaran yang lebih efektif.Hasil penelitian menunjukan bahwa ada perbedaan prestasi belajar matematika antara peserta didik yang diremidi menggunakan metode tutor sebaya dengan peserta didik yang diremidi menggunakan metode tanya jawab. Penerapan metode pembelajaran tutor sebaya lebih efektif daripada metode pembelajaran tanya jawab.
\end{abstract}

Kata Kunci: Metode Tutor Sebaya, Metode Tanya Jawab, Pengajaran Remidial, Prestasi Belajar

\section{PENDAHULUAN}

Matematika adalah mata pelajaran yang dianggap sulit bagi sebagian peserta didik di SD, SMP, dan SMA. Tidak sedikit peserta didik memiliki nilai rendah pada mata pelajaram matematika, padahal matematika sebagai suatu mata pelajaran yang mempunyai nilai cukup memegang peranan penting, baik pola pikirnya dalam membentuk peserta didik menjadi berkualitas maupun terapannya dalam kehidupan sehari-hari karena matematika merupakan salah satu sarana berpikir untuk mengkaji sesuatu secara logis dan sistematis. Oleh sebab itu, matematika dianggap penting untuk dikuasai sedini mungkin oleh para peserta didik.

Menurut Mukhtar dan Suharsimi (2003:1), "proses pengajaran merupakan integral dari proses belajar-mengajar yang menghendaki ketuntasan mencapai tujuan/kompetensi atau mencapai tujuan secara optimal". Ketuntasan belajar atau mencapai tujuan yang optimal itu secara eksplisit dicantumkan dalam kurikulum, tetapi setiap daerah/sekolah diberikan kebebasan menentukan patokan ketuntasan sesuai dengan situasi dan kondisi atau keadaan sekolah yang bersangkuatan. 
Seorang guru yang profesional dalam mengelola pengajarannya, ketika menghadapi persoalan ini tidak akan tinggal diam, karena jika kesulitan belajar peserta didik tersebut dibiarkan, maka tujuan pembelajaran tidak akan tercapai dengan baik. Oleh karena itu, seorang guru harus dapat mengidentifikasi setepat mungkin faktor-faktor yang menyebabkan timbulnya kesulitan belajar pada diri peserta didik tersebut. Setiap peserta didik memiliki berbagai perbedaan individual, hal ini menyebabkan adanya perbedaan tingkat penguasaan belajar peserta didik. Untuk menghadapi keanekaragaman dan tingkat keberhasilan peserta didik, maka proses pembelajaran saat ini berorientasi pada prinsip belajar tuntas yang berimplikasi adanya pelaksanaan program perbaikan (remidial) dan pengayaan. Program remidial untuk mengoreksi kesalahan belajar peserta didik dan membantu mengatasi kesulitan belajar yang dialami sedangkan program pengayaan untuk memperluas dan memperdalam pelajaran yang diterapkan pada peserta didik yang sudah tuntas.

Selama ini metode pembelajaran yang sering digunakan di kelas XI IPS MAN Kota Tegal dalam mata pelajaran matematika adalah metode ceramah. Metode ini digunakan karena banyaknya materi yang disampaikan sedangkan waktu yang tersedia terbatas. Dengan metode tersebut ternyata prestasi belajar yang dicapai oleh peserta didik kelas XI IPS MAN Kota Tegal kurang memuaskan karena nilainya dibawah KKM (Kriteria Ketuntasan Minimal), yaitu 75. Terutama untuk kompetensi dasar Fungsi Limit, hal ini dapat dilihat dari hasil ulangan harian 3 tahun terakhir, yang tersaji pada tabel berikut ini.

Tabel 1.Hasil Ulangan Harian 3 Tahun Terakhir pada Kompetensi Dasar Fungsi Limit

\begin{tabular}{|c|c|c|c|c|c|c|}
\hline No & Tahun & $\begin{array}{c}\text { Jumlah } \\
\text { Peserta Didik }\end{array}$ & KKM & $\begin{array}{c}\text { Nilai } \\
\text { Terendah }\end{array}$ & $\begin{array}{c}\text { Nilai } \\
\text { Tertinggi }\end{array}$ & $\begin{array}{c}\text { Rata- } \\
\text { rata }\end{array}$ \\
\hline 1 & 2009 & 152 & 70 & 25 & 70 & 45 \\
2 & 2010 & 153 & 70 & 35 & 65 & 47 \\
3 & 2011 & 156 & 72 & 40 & 60 & 50 \\
\hline
\end{tabular}

Sumber: Arsip Nilai Peserta Didik Kelas XI IPS MAN Kota Tegal Tahun Ajaran 2012.

Para peserta didik yang mendapatka nilai dibawah KKM harus mendapatkan pengajaran remidial dimana metode yang dipakai disesuaikan dengan karakteristik peserta didik yang mengalami kesulitan belajar. Beberapa metode yang dapat digunakan dalam pengajaran remidial yaitu metode pemberian tugas, diskusi, tanya jawab, kerja kelompok, tutor sebaya, dan pengajaran individual. Dalam penelitian ini, peneliti menggunakan metode tutor sebaya dan tanya jawab.

\section{TINJAUAN PUSTAKA}

Mengajar pada hakekatnya suatu proses, yakni proses mengatur, mengorganisasi lingkungan yang ada disekitar peserta didik sehingga menumbuhkan dan mendorong peserta didik belajar. Hubungan pendidikan dengan pengajaran yaitu pada proses pendidikan akan menghasikan suatu produk, dimana produk tersebut akan terwujud melalui proses pengajaran dengan strategi pelaksaan melalui bimbingan, pengajaran, dan pelatihan.

\section{Pendidikan}

Menurut Syaiful (2003:2), "ilmu pendidikan disebut juga pedagogik yang merupakan terjemahan dari bahasa Inggris yaitu "pedagogics".Pedagogics itu sendiri berasal dari bahasa Yunani yaitu "pais" yang artinya anak, dan "again"yang artinya 
bimbingan". Dengan adanya konsep pendidikan seumur hidup (lifelong education) yang berarti pendidikan berlangsung sampai mati tumbuh dalam dunia pendidikan maka pengertian pendidikan semakin luas, dimana setelah anak dewasa tetap masih dalam proses pendidikan tetapi tingkat pendidikannya berbeda dengan sebelum mencapai kedewasaan.pendidikan dapat dimaknai sebagai proses mengubah tingkah laku peserta didik agar menjadi manusia dewasa yang mampu hidup mandiri dan sebagai anggota masyarakat dalam lingkungan alam sekitar dimana individu itu berada.

Fungsi pendidikan yaitu menghilangkan segala sumber penderitaan rakyat dari kebodohan dan ketertinggalan (kemiskinaan); Pendidikan dapat meningkatkan kesejahteraan; dan Membimbing anak ke arah suatu nilai yang kita nilai tinggi. Dan UUSPN No. 20 tahun 2003 menyatakan pendidikan nasional berfungsi mengembangkan kemampuan dan membentuk watak serta perabadan bangsa yang bermartabat dalam rangka mencerdaskan kehidupan bangsa.

\section{BelajarMatematika}

Menurut Gage(Syaiful, 2003:13,14,17), belajar adalah sebagai suatu proses dimana suatu organisme berubah perilakunya sebagai akibat dari pengalaman; Skinner, belajar adalah suatu proses adaptasi atau penyesuaian tingkah laku yang berlangsung secara progresif; Gagne, belajar adalah seperangkat proses kogntif yang mengubah sifat stimulasi lingkungan, melewati pengelolahan informasi, dan menjadi kapabilitas baru.

Ciri yang menandakan seorang anak telah melakukan aktivitas belajar diantaranya akan terjadi perubahan tingkah laku yang diperoleh sebagai hasil dari belajar adalah sebagai berikut:Perubahan yang terjadi secara sadar; Perubahan yang terjadi relative lama; dan Perubahan yang terjadi mencakup seluruh aspek tingkah laku baik dalam sikap kebiasaan, keterampilan dan pengetahuan yang meliputi aspek kognitif, afektif, dan psikomotorik.

Menurut Halim Fathani (2011), "matematika merupakan ratu dari ilmu pengetahuan dimana materi matematika di perlukan di semua jurusan yang di pelajarai oleh semua orang". Untuk mendeskripsikan definisi kata matematika para matematikawan belum pernah mencapai satu titik "puncak" kesepakatan yang "sempurna". Penjelasan mengenai apa dan bagaimana sebenarnya matematika itu, akan terus mengalami perkembangan seiring dengan pengetahuan dan kebutuhan manusia serta laju perubahan zaman. Beberapa ahli telah mencoba dan merumuskan serta membuat tafsiran tentang matematika.

Fungsi matematika yaitu: Mengembangkan kemampuan menghitung, mengukur, menurunkan, dan menggunakan rumus matematika yang diperlukan dalam kehidupan sehari-hari melalui pengukuran dan geometri, aljabar, peluang, statistik, kalkulus, dan trigonometri. Serta Mengembangkan kemampuan mengkomunikasikan gagasan melalui model matematika yang dapat berupa kalimat matematika dan persamaan matematika, diagram, grafik atau tabel. Dan tujuan umum pendidikan matematika ditekankan kepada siswa untuk memiliki: Kemampuan yang berkaitan dengan matematika yang dapat digunakan dalam memecahkan masalah matematika, pelajaran lain ataupun masalah yang berkaitan dengan kehidupan nyata; Kemampuan menggunakan matematika sebagai alat komunikasi; dan Kemampuan menggunakan matematika sebagai cara bernalar yang dapat dialihgunakan pada setiap keadaan, seperti berpikir kritis, berpikir logis, berpikir sistematis, bersifat objektif, bersifat jujur, bersifat disiplin dalam memandang dan menyelesaikan suatu masalah. 


\section{Prestasi Belajar}

Prestasi belajar merupakan dambaan bagi setiap peserta didik yang sedang mengikuti proses pembelajaran di sekolah serta dambaan bagi orang tua maupun guru. Menurut Hamdani (2011:137), prestasi belajar adalah hasil dari suatu kegiatan yang telah dikerjakan, diciptakan, baik secara individual maupun kelompok. Prestasi tidak akan pernah dihasilkan selama seseorang tidak melekukan kegiatan; Menurut Purwadarminta, prestasi belajar adalah hasil yang telah dicapai (dilakukan, dikerjakan, dan sebagainya); dan Menurut Qadar, prestasi belajar adalah hasil yang telah diciptakan, hasil pekerjaan, hasil yang menyenangkan hati yang diperoleh dengan jalan keuletan.

Dari beberapa pengertian yang telah dikemukakan sebelumnya, dapat disimpulkan bahwa prestasi belajar adalah hasil yang telah dicapai oleh seseorang setelah melakukan suatu kegiatan.

\section{Keefektifan}

Keefektifan berasal dari kata efektif yang berarti mempunyai akibat dan pengaruh. Sedangkan keefektifan adalah keberhasilan dari suatu usaha (KBI, 2008:374). Jadi keefektifan yang dimaksud dalam penelitian ini adalah keberhasilan dari suatu usaha pengajaran yang dimaksud dalam pembelajaran remidial pada materi pokok fungsi limit yang menggunakan metode tutor sebaya dibanding dengan metode tanya jawab.

Pendapat Sri Esti (2008:263), pengelola kelas adalah inti dari suatu organisasi yang efektif. Seorang manager yang efektif adalah seorang yang menkoordinasi dan menyusun kegiatan untuk menentukan tujuan dan sasaran khusus. Disamping itu, harapan orang tua dan masyarakat supaya anak-anak atau siswa mencapai tujuan belajar untuk masa depan mereka sekarang lebih besar dibandingkan pada zaman dahulu dalam sejarah.

Mengelola kelas adalah suatu keterampilan yang memungkinkan guru mengajar dan peserta didik belajar. Tanpa pengelolaan dan pengaturan yang efektif maka proses belajar mengajar akan terganggu. Guru dalam kelas mengatur sejumlah tugas secara rinci dalam mengajar setiap hari, diantara tugas utama guru adalah merencanakan dan mempersiapkan pengajaran, melanjutkan interaksi dengan peserta didik, melaksanakan pengajaran, menggerakan peserta didik melalui kegiatan yang berbeda, mengembangkan tata tertib, menciptan lingkungan untuk belajar, mengorganisasi waktu dan materi pengajaran serta membuat tes dan melakukan penilaian.

Jadi hasil belajar semakin mendekati sasaran, berarti semakin tinggi keefektifannya. Dan penelitian ini akan meneliti keefektifan stratesi pembelajaran antara metode tutor sebaya dengan metode tanya jawab dalam pengajaran remidial matematika terhadap prestasi belajar peserta didik.

\section{Pengajaran Remidial}

Tidak semua peserta didik mencapai ketuntasan dalam belajar, artinya ada peserta didik yang tidak mencapai standar kompetensi yang telah ditetapkan dalam pelaksanaan pembelajaran yang biasa dilaksanakan. Peserta didik yang "terlambat" dalam mencapai ketuntasan menguasai materi pelajaran, diadakan pembelajaran khusus, yaitu pembelajaran remidial. Menurut Mariana (2003:50) pengajaran remidial merupakan upaya membantu siswa memecahkan kesulitan belajar yang dialami dalam pembelajaran regular di kelas. Dengan demikian pembelajaran remedial juga disebut pembelajaran "pengobatan" agar permasalahan yang ditemui diperoleh jawabannya oleh siswa.

Menurut Apriliana (2010) "metode mengajar dapat diartikan sebagai suatu cara yang harus dilalui untuk menyajikan bahan pengajaran agar tercapai tujuan pengajaran". Hakekat tujuan merupakan petunjuk bagi guru untuk memilih satu atau serangkaian metode yang efektif. 
Adapun faktor-faktor yang harus dipertimbangkan dalam pemilihan dan penggunaan metode mengajar secara efektif adalah: disesuaikan dengan tujuan yang hendak dicapai; bahan pengajaran merupakan materi yang perlu dipelajari pesertadidik agar tujuan yang telah ditetapkan dapat dicapai; guru harus mampu memilih dan menggunakan metode yang tepat; guru harus mempertimbangkan faktor anak didik, yaitu tingkat pengetahuan, kemampuan, dan kematangan anak didik; dan situasi mengajar berlainan sesuai dengan yang diperlukan.

Beberapa metode yang dapat dilaksanakan dalam pengajaran remidial yaitu: Tanya jawab, Tutor sebaya, Pemberian tugas, Diskusi, Kerja kelompok, dan Pengajaran individual. Dalam penelitian ini metode yang digunakan adalah metode tutor sebaya dan metode tanya jawab. Menurut Mukhtar dan Rusmini (2003:66), tutor sebaya adalah kegiatan bantuan perbaikan yang diberikan oleh teman-teman sekelas dengan siswa yang mengalami kesulitan belajar. Adakalanya seorang siswa lebih mudah menerima keterangan yang diberikan oleh kawan sebangku atau kawan-kawannya untuk melaksakan program perbaikan.

Menurut Apriliana (2010) "metode tanya jawab merupakan bentuk interaksi langsung secara lisan antara guru dengan murid". Dalam hubungan ini guru dapat mengetahui peserta didik yang mengalami kesulitan belajar dan mengenal jenis atau sifat kesulitan belajar yang dihadapi melalui tanya jawab. Tanya jawab dapat dilakukan secara individu maupun secara kelompok dengan peserta didik.

\section{METODE}

Pendekatan yang digunakan dalam penelitian ini adalah pendekatan kuantitatif dimana pendekatan ini melakukan perhitungan yang diperoleh dari hasil tes uji pada sampel. Jenis yang digunakan dalam penelitian ini adalah eksperimen. Menurut Sudjana (2009:56), dimana eksperimen mengkaji dua variabel atau lebih. Peneliti melakukan manipulasi atau perlakuan terhadap variabel bebas, melakukan pengukuran sendiri terhadap variabel bebas dan variabel terikat.

Varibel bebas adalah variabel perlakuan atau sengaja dimanipulasi untuk diketahui intensitasnya atau pengaruhnya terhadap variabel terikat. Dalam penelitian ini yang menjadi variabel bebas yaitu metode tutor sebaya adalah peserta didik yang lebih pandai ditunjuk untuk membantu teman-temannya yang mengalami kesulitan belajar dan metode tanya jawab adalah cara menyajikan bahan pelajaran dalam bentuk pertanyaan, baik lisan maupun tulis dari guru ke peserta didik atau sebaliknya.

Variabel terikat adalah variabel yang timbul akibat variabel bebas, atau respon dar variabel bebas. Dalam penelitian ini yang menjadi variabel terikat yaitu prestasi belajar dalam pengajaran remidial matematika materi fungsi limit.Adapun desain dalam penelitian ini sebagai berikut.

Tabel 2. Desain Penelitain

\begin{tabular}{|c|c|c|c|}
\hline No & Grup & Variabel Terikat & Postes \\
\hline 1 & Eksperimen 1 & X1 & Y2 \\
2 & Eksperimen 2 & X2 & Y2 \\
\hline
\end{tabular}

Keterangan:

X1: Metode Tutor Sebaya

X2: Metode Tanya Jawab

Y2: Prestasi Belajar

Menurut Arikunto (2006:130), "populasi adalah keseluruhan obyek penelitian". Populasi dalam penelitian ini adalah para siswa kelas XI IPS Madrasah Aliyah Negeri Kota Tegal yang nilai ulangan harinya dibawah KKM pada materi fungsi limit, dimana 
terdiri dari 4 kelas yaitu kelas XI IPS 1, kelas XI IPS 2, kelas XI IPS 3, dan kelas XI IPS 4. Jumlah populasinya adalah 154 peserta didik, setiap kelas rata-rata terdiri dari 38 peserta didik.

Pada penelitian ini hanya akan meneliti sebagian dari populasi, maka penelitian ini disebut penelitian sampel. Menurut Arikunto (2006:131), "sampel adalah sebagian atau wakil dari populasi". Penentuan sampel dilihat dari tes awal yaitu siswa yang mendapat nilai ulangan harian dibawah KKM pada materi fungsi limit, dari empat kelas diambil dua kelas secara acak untuk sampel penelitian. Dimana kelas XI IPS 1 dengan 38 peserta didik akan diajarkan menggunakan metode tutor sebaya dan kelas XI IPS 2 dengan 38 peserta didik akan diajarkan menggunakan metode tanya jawab.

Dalam penelitian ini peneliti menggunakan beberapa metode diantaranya metode dokumentasi untuk mengetahui para peserta didik yang menjadi populasi dan sampel serta untuk mengetahui nilai ulangan harian pokok bahasan fungsi limit. Metode tes, penulis menggunakan instrumen berupa soal tes yang disusun dalam bentuk pilihan ganda sebanyak 25 soal dan lama waktunya $2 \times 45$ menit, setiap soal terdiri dari 5 pilihan yaitu: $\mathrm{a}, \mathrm{b}, \mathrm{c}, \mathrm{d}$, dan e. Untuk mengetahui data nilai peserta didik dengan kriteria jika menjawab benar diberi nilai 1 dan jika menjawab salah diberi nilai 0 .

Instrumen penelitian ini berupa soal pilihan ganda dengan jumlah 25 soal yang dikerjakan dalam waktu $2 \times 45$ menit. Sebelum instrumen digunakan maka terlebih dahulu diujicobakan di kelas uji coba. Setelah diujicoba, maka hasil tes dianalisis mencakup validitas, reabilitas, tingkat kesukaran dan daya beda.

\section{Uji Prasyarat Analisis}

Uji prasyarat penelitian dimaksudkan untuk mengukur atau menguji kesamaan awal kedua kelompok perlakuan. Adapun uji prasyarat ini menggunakan uji normalitas untuk mengetahui sampel normal apa tidak dimana menggunakan uji Lilliefors. Dan uji homogenitas untuk mengetahui homogenitas sample menggunakan uji Bartlett.

\section{Uji Hipotesis}

Guna membuktikan hipotesis digunakan norma-norma statistik. Untuk dapat menganalisis perbedaan prestasi belajar matematika peserta didik yang diremidi menggunakan metode tutor sebaya dengan siswa yang diremidi menggunakan metode tanya jawab, digunakan uji-t dua pihak.

\section{HASIL DAN PEMBAHASAN \\ Hasil Penelitian}

Dalam penelitian ini data prestasi belajar matematika peserta didik diperoleh dari nilai tes ulangan remidial pada fungsi limit dengan bentuk soal tes pilihan ganda yang diberikan kepada peserta didik kelas XI IPS 1 dan kelas XI IPS 2 Madrasah Aliyah Negeri Kota Tegal Tahun Pelajaran 2011/2012.Sampel yang digunakan dalam penelitian ini peserat didik yang nilai ulangan harian pada materi fungsi limit dibawah KKM yaitu sampel kelas kelompok eksperimen I yaitu sampel kelompok yang menggunakan metode pembelajaran tutor sebaya sebanyak 38 peserta didik dan sampel kelompok eksperimen II yaitu sampel kelompok yang menggunakan metode pembelajaran tanya jawab sebanyak 38 peserta didik.

1. Prestasi belajar matematika peserta didik yang menggunakan metode pembelajaran tutor sebaya.

Prestasi belajar matematika yang akan dibandingkan dalam penelitian ini diambil dari tes sejumlah 25 soal pilihan ganda. Dari data tersebut, kemudian dapat 
dideskripsikan prestasi belajar matematika peserta didik kelas XI IPS 1 yang menggunakan metode pembelajaran tutor sebaya di Madrasah Aliyah Negeri Kota Tegal seperti terlihat pada tabel 3 berikut:

Tabel 3. Prestasi Belajar MatematikaMetode Pembelajaran Tutor Sebaya

\begin{tabular}{|c|c|c|c|}
\hline No & Interval Kelas & fi & Frekuensi Relatif (\%) \\
\hline 1 & $75-78$ & 6 & 15,790 \\
\hline 2 & $79-82$ & 6 & 15,790 \\
\hline 3 & $83-86$ & 11 & 28,947 \\
\hline 4 & $87-90$ & 10 & 26,316 \\
\hline 5 & $91-94$ & 0 & 0 \\
\hline 6 & $95-98$ & 5 & 13,158 \\
\hline \multicolumn{2}{|r}{ Jumlah } & 38 & 100 \\
\hline
\end{tabular}

Mengacu pada data yang terlihat pada tabel 3 tersebut maka dapat diperoleh nilai-nilai mean (rata-rata), median (nilai tengah), modus (nilai yang sering muncul), nilai maksimal dan minimal sebagai berikut:

a. Nilai mean sebesar 85,263 dapat diartikan bahwa rata-rata prestasi belajar matematika dari jumlah sampel 38 peserta didik yang menggunakan metode pembelajaran tutor sebaya di kelas XI IPS 1 Madrasah Aliyah Negeri Kota Tegal adalah baik.

b. Median sebesar 85 dapat diartikan bahwa dari sebaran data prestasi belajar matematika dari jumlah sampel 38 peserta didik yang menggunakan metode pembelajaran tutor sebaya di kelas XI IPS 1 Madrasah Aliyah Negeri Kota tegal adalah baik.

c. Modus dari jumlah sampel 38 peserta didik yang menggunakan metode pembelajaran tutor sebaya di kelas XI IPS 1 Madrasah Aliyah Negeri Kota Tegal bernilai 85 dengan proporsi sebesar $28,947 \%$.

d. Dari 38 anggota sampel yang menggunakan metode pembelajaran tutor sebaya di kelas XI IPS 1 Madrasah Aliyah Negeri Kota Tegal diperoleh prestasi belajar matematika tertinggi 95 dan terendah sebesar 75 .

2. Prestasi belajar matematika peserta didik yang menggunakan metode pembelajaran tanya jawab.

Prestasi belajar matematika yang akan dibandingkan dalam penelitian ini diambil dari tes sejumlah 20 soal pilihan ganda. Dari data tersebut, kemudian dapat dideskripsikan prestasi belajar matematika peserta didik kelas XI IPS 2 yang menggunakan metode pembelajaran tanya jawab di Madrasah Aliyah Negeri Kota Tegal seperti terlihat pada tabel 4 .

Tabel 4. Prestasi Belajar MatematikaMetode Pembelajaran Tanya Jawab

\begin{tabular}{|c|c|c|c|}
\hline No & Kelas Interval & fi & f rel(\%) \\
\hline 1 & $75-77$ & 8 & 21,053 \\
\hline 2 & $78-80$ & 9 & 23,684 \\
\hline 3 & $81-83$ & 0 & 0 \\
\hline 4 & $84-86$ & 14 & 36,842 \\
\hline 5 & $87-89$ & 0 & 0 \\
\hline 6 & $90-92$ & 7 & 18,421 \\
\hline \multicolumn{2}{|r|}{ Jumlah } & 38 & 100 \\
\hline
\end{tabular}


Mengacu pada data yang terlihat pada tabel 4 tersebut maka dapat diperoleh nilai-nilai mean (rata-rata), median (nilai tengah), modus (nilai yang sering muncul), nilai maksimal dan minimal sebagai berikut:

a. Nilai mean sebesar 82,632 dapat diartikan bahwa rata-rata prestasi belajar matematika dari jumlah sampel 38 peserta didik yang menggunakan metode pembelajaran tanya jawab di kelas XI IPS 2 Madrasah Aliyah Negeri Kota Tegal adalah sedang.

b. Median sebesar 85 dapat diartikan bahwa dari sebaran data prestasi belajar matematika dari jumlah sampel 38 peserta didik yang menggunakan metode pembelajaran tanya jawabdi kelas XI IPS 2 Madrasah Aliyah Negeri Kota Tegal adalah baik.

c. Modus dari jumlah sampel 38 peserta didik yang menggunakan metode pembelajaran tanya jawab di kelas XI IPS 2 Madrasah Aliyah Negeri Kota Tegal bernilai 85 dengan proporsi sebesar $36,84 \%$.

d. Dari 38 anggota sampel yang menggunakan metode pembelajaran tanya jawab di kelas XI IPS 2 Madrasah Aliyah Negeri Kota Tegal diperoleh prestasi belajar matematika tertinggi 90 dan terendah sebesar 75 .

Berdasarkan perhitungan uji normalitas, diperoleh:Untukelas eksperimen INilai $\mathrm{L}_{\text {hitung }}=0,113$ dan $\mathrm{L}_{\text {tabel }}=0,144$ sehingga $L_{\text {hitung }}<L_{\text {tabel }}$, maka prestasi belajar matematika kelas kelompok eksperimen I berdistribusi normal.Sedangkan kelas eksperimen IINilai $\mathrm{L}_{\text {hitung }}=0,142$ dan $\mathrm{L}_{\text {tabel }}=0,144$ sehingga $L_{\text {hitung }}<L_{\text {tabel }}$, maka prestasi belajar matematika kelas kelompok eksperimen II berdistribusi normal.

Dari hasil analisis uji homogenitas sampel pada kelompok eksperimen I diperoleh harga $\mathrm{X}^{2}{ }_{\text {hitung }}$ sebesar -133. Harga $\mathrm{X}^{2}{ }_{\text {tabel }}$ dengan taraf signifikansi $5 \%$ dan $d k=$ $(2-1)=1$ adalah 3,841 . Sehingga pada kelompok sampel tersebut adalah homogen, karena $x_{\text {hitung }}^{2}<x^{2}$ tabel.

Dari hasil perhitungan menggunakan uji-t dua pihak diperoleh nilai $t_{\text {hitung }}=$ 1,980. Nilai $t_{\text {hitung }}$ tersebut kemudian dikonsultasikan dengan $t_{\text {tabel }}$ dengan derajat kebebasan 76 pada taraf signifikan 5\% dimana diperoleh $t_{\text {tabel }}=1,967$. Sehingga $t_{\text {hitung }}>t_{\text {tabel }}$ maka Ho ditolak dan menerima Ha yang menayatakan "ada perbedaan prestasi belajar matematika antara peserta didik yang diremidi menggunakan metode tutor sebaya dengan peserta didik yang diremidi menggunakan metode tanya jawab".

Selanjutnya menentukan metode pembelajaran manakah yang lebih efektif yaitu dengan menggunakan uji-t satu pihak, diperoleh $\mathrm{t}_{\text {hitung }}=2,800$ kemudian dikonsultasikan dengan $t_{\text {tabel }}$ dengan $\mathrm{dk}=38$ dan taraf signifikansi $5 \%$ didapat $\mathrm{t}_{\text {tabel }}=1,645$. Karena $t_{\text {hitung }}>\mathrm{t}_{\text {tabel }}$ maka dapat diambil kesimpulan bahwa pembelajaran remidial dengan menggunakan metode tutor sebaya lebih efektif dari pada pembelajaran remidial dengan menggunakan metode tanya jawab.

\section{Pembahasan}

Setelah diadakan pengujian kepada kedua kelompok dengan perlakuan yang berbeda yaitu kelompok eksperimen I dengan metode pembelajaran tutor sebaya dan kelompok eksperimen II dengan metode pembelajaran tanya jawab menunjukan bahwa dalam penelitian ini terdapat perbedaan antara prestasi belajar matematika antara peserta didik yang diremidi menggunakan metode tutor sebaya dengan peserta didik yang diremidi menggunakan metode tanya jawab pada peserta didik kelas XI IPS Madrasah Aliyah Negeri Kota Tegal. Hal ini dapat dibuktikan dari perhitungan uji-t satu pihak yang menghasilkan kesimpulan metode pembelajaran tutor sebaya lebih efektif dari pada metode pembelajaran tanya jawab, dimana nilai rata-rata peserta didik yang diajarkan 
menggunakan metode pembelajaran tutor sebaya lebih baik dari pada nilai rata-rata peserta didik yang diajarkan menggunakan metode pembelajaran tanya jawab.

Dilihat dari nilai ulangan remidial materi fungsi limit yang diatas KKM paling baik, prestasi belajar matematika peserta didik yang diajarkan menggunakan metode pembelajaran tutor sebaya lebih baik. Hal ini disebabkan karena peserta didik diajarkan oleh temannya sendiri sehingga lebih bersemangat, lebih aktif, dan tidak malu dalam bertanya. Dari pertama pembelajaran hingga terakhir pembelajaran pada kelas eksperimen I ini menarik bagi peserta didik, sehingga kegiatan pembelajaran dengan metode pembelajaran tutor sebaya sesuai yang diharapkan. Sedangkan prestasi belajar matematika peserta didik yang diajarkan menggunakan metode tanya jawab kurang baik. Hal ini disebabkan peserta didik kurang percaya diri sehingga malu untuk bertanya, peserta didik tidak tahu apa yang harus ditanyakan, dan peserta didik takut ditanya balik jika bertanya.

Adapun keterbatasan penelitian ini antara lain: Waktu penelitian bersamaan dengan persiapan ujian nasional sehingga peserta didik kelas X dan XI sering diliburkan. Hal ini mengakibatkan waktu penelitian tidak sesuai dengan target, yang seharusnya dilakukan paling tidak 5 kali pertemuan menjadi 3 kali pertemuan; dan peserta didik kurang paham pada materi yang diajarkan (pada metode tutor sebaya 16\% dan metode tanya jawab 21\%) karena waktu yang tersedia sedikit sedangkan materi yang diajarkan banyak.

Populasi penelitian jumlahnya hanya 4 kelas sehingga sampel tiap metode pembelajaran hanya satu kelas, hal ini mengakibatkan perlu dikaji ulang karena hasil perhitungan uji homogenitas pada sampel penelitian ini tidak dapat mewakili untuk jumlah populasi yag besar.

Berdasarkan paparan di atas dapat disimpulkan bahwa pembelajaran menggunakan metode tutor sebaya dalam pengajaran remidial matematika sangat berguna dan dapat meningkatkan prestasi belajar peserta didik karena peserta didik yang tadinya tidak tertarik dengan pembelajaran menjadi tertarik dan mengurangi kebosanan.

Penelitian ini berhubungan dengan penelitian yang dilakukan oleh Khusnul Arofah (2010) yang menyimpulkan: "Hasil evaluasi menunjukan bahwa prestasi belajar siswa meningkat dari siklus I ke siklus II, serta memenuhi standar kelulusan minimum (SKM) sekolah. Pada siklus I hanya 46,67\% siswa yang tuntas belajar (nilai minimum $5,5)$ sehingga belum memenuhi indicator keberhasilan (75\% siswa tuntas belajar) belum terpenuhi. Pada siklus II $80 \%$ siswa tuntas belajar, sehingga indicator keberhasilan terpenuhi."

\section{PENUTUP} Simpulan

Berdasarkan landasan teori dan didukung analisis data serta mengacu pada perumusan masalah yang telah diuraikan pada bab sebelumnya, maka dapat diambil kesimpulan sebagai berikut:

1. Dilihat dari hasil presatsi belajar matematika yang berbeda, maka dapat diketahui bahwa ada perbedaan prestasi belajar matematika antara peserta didik yang diremidi menggunakan metode tutor sebaya dengan peserta didik yang diremidi menggunakan metode tanya jawab.

2. Pembelajaran remidial dengan menggunakan metode tutor sebaya lebih efektif dari pada pembelajaran remidial dengan menggunakan metode tanya jawab 
Saran

Berdasarkan hasil penelitian, ada beberapa saran dalam meningkatkan prestasi belajar matematika peserta didik, antara lain:

1. Bagi Peserta Didik

Untuk meningkatkan motivasi belajar peserta didik pada bidang studi matematika, hendaknya sering diadakan latihan soal dengan menggunakan metode pembelajaran tutor sebaya.

2. Bagi Guru

a. Guru bidang studi matematika, diharapkan dapat meningkatkan kompetensi dirinya sehingga mampu mengajar dengan efektif dan efisien serta dapat menerapkan metode pembelajaran matematika yang sesuai dan lebih banyak melibatkan peran peserta didik agar tidak merasa bosan dengan pelajaran matematika.

b. Dalam upaya meningkatkan pengetahuan, ketrampilan dan prestasi belajar matematika, metode pembelajaran tutor sebaya dapat dijadikan satu rujukan untuk meningkatkan prestasi peserta didik ke arah yang lebih baik.

3. Bagi Peneliti Selanjutanya

Perlu diadakan penelitian lebih lanjut pada populasi lain yang jumlahnya lebih besar dan dengan menggunakan metode-metode pengajaran remidial yang lainnya yang diduga dapat meningkatkan prestasi belajar matematika.

\section{DAFTAR PUSTAKA}

Arikunto, Suharsimi. 2006. Prosedur Penelitian Suatu Pendekatan. Jakarta: Rineka Cipta.

Hamdani. 2011. Strategi Belajar Mengajar. Bandung: Pustaka Setia.

Hartanti, Apriliana. 2010. Pengajaran Remidial. Online. http://www.makalahpsikologi.blogspot.com/2010/01/pengajaran-remidial.html. (12 Desember 2011)

Mariana, Made Alit. 2003. Pembelajaran Remidial. Jakarta: Depdiknas Direktorat Jendral Pendidikan Dasar dan Menengah Direktorat Tenaga Kependidikan.

Mukhtar dan Rusmini. 2003. Pengajaran Remidial, Teori dan Penerapan dalam Pembelajaran. Jakarta: Fifa Mulia Sejahtera.

Nurjanah, Nana. 2009. Tuntunan Penyusunan Karya Ilmiah. Bandung: Sinar Baru Algensindo.

Sagala, Syaiful. 2003. Konsep dan Makna Pembelajaran. Bandung: Alfabeta.

Susongko, Purwo. 2010. Penelitian Hasil Belajar. Tegal: UPS Tegal.

Yahya, A Halimfathani. 2006. Pengertian Matematika. Online. http://aadesanjaya.blogspot.com/2011/06/pengertian-matematika.html. (27 Oktober 2011)

Khunul Arofah. 2010. Upaya Meningkatkan Prestasi Belajar Matematika Melalui pembelajaran Remidial Dengan menggunakan Metode Tutor Sebaya Di Madrasah Aliyah Ibbnu Qoyyim YogyakartaKelas X. 